\title{
Groundwater flow and geochemical modeling of the Acque Albule thermal basin (Central Italy): a conceptual model for evaluating influences of human exploitation on flowpath and thermal resource availability
}

\author{
Andrea Del Bon ${ }^{1}$, Chiara Sbarbati ${ }^{1}$, Elio Brunetti ${ }^{2}$, Valentina Carucci ${ }^{3}$, \\ Alessandro Lacchini ${ }^{1}$, Valentina Marinelli ${ }^{1}$, Marco Petitta ${ }^{1 *}$
}

${ }^{1}$ Dipartimento di Scienze della Terra, Università "La Sapienza", Rome, Italy

${ }^{2}$ Syndial - Eni, San Donato Milanese, Italy

${ }^{3}$ Ambiente SC Ingegneria e Laboratori, Rome, Italy

Received: January 28, 2015; accepted: January 28, 2015

\begin{abstract}
Although the Acque Albule Basin has been studied since the middle of the 19th century, a comprehensive geologic conceptual model of the area has not yet been developed. The natural setting has been heavily modified by anthropic activities. Rapid evolution during the last 25 years has caused many interferences, which have led to a drastic increase of the hazards and linked risks, mainly related to water resource overexploitation and subsidence.

The implementation of an exhaustive framework has become mandatory for environmental and management purposes. Starting from a critical review of previous studies, hydrogeologic and hydrogeochemical surveys and related numerical modeling have been carried out in order to achieve a quantitative understanding of the active phenomena and processes.

Several hydrogeologic issues have been addressed concerning aquifer recharge areas and the different flowpaths of groundwater in respect to their division into a shallow and a deep circuit. Account has been taken of the groundwater chemistry as a function of water-rock interactions and mixing processes with uprising fluids. Different scenarios of groundwater flow in the Acque Albule aquifer have been built, using previously available piezometric measurements and the hydrodynamic parameters determined by in situ tests. These results led to the formulation of an updated hydrogeologic conceptual model to be further implemented, in which past, present and future anthropic instances and the potential of natural resources of the area have been included and taken into account. A sound conceptual model must rely on the design and development of a logical geo-database in which information is stored, updated and processed. This operational framework can result in a useful tool for land management, surveys planning and design, hazard and risk evaluation, identification of best practices and economic development of the area.
\end{abstract}

Keywords: conceptual model, subsidence, overexploitation, dewatering, thermal resources, hydrogeochemistry, isotope geochemistry, groundwater mixing

\footnotetext{
* Corresponding author: Piazzale Aldo Moro 5, 00185 Roma, Italy;

E-mail: marco.petitta@uniroma1.it
} 


\section{Introduction}

Urbanization directly interacts with the correct management of water resource; in fact the increase of urban settlements all over the world has a marked impact on aquifers underlying cities (Foster et al. 2011). One of the first issue in urban areas is to satisfy the water demand of larger cities in terms of quantity and quality (Foster et al. 1998; Taniguchi et al. 2009). Specifically, as a function of the hydrogeologic setting, human activities can: i) modify the recharge mechanisms due to the continuous paving over of the potential recharge area (Foster and Vairavamoorthy 2013), ii) expose the aquifer to different pollution sources in the form of losses from sewer pipelines or percolation of contaminants, especially in an industrial area. In addition, rapid urbanization processes (Jenerette and Larsen 2006; Villholth 2006) and/or mining operations (Whittington and Price 2013) promote groundwater overexploitation processes. The effects of this overexploitation reflected, as mentioned before, on groundwater quality (Schreiber et al. 2000; Howard 2007; Abe et al. 2014), on changes in groundwater availability and springs discharge and on geotechnical properties causing land subsidence (Tomas et al. 2010; Galloway and Burbey 2011; Julio-Miranda et al. 2012; Sayyaf et al. 2013). An example of the multiple effects of groundwater exploitation is the case of the Acque Albule Basin (central Italy), the subject of this paper.

The Acque Albule Basin is a morphological depression located about $20 \mathrm{~km}$ east of Rome (Central Italy) at the eastern margin of the Central Apennine fold - thrust belt, covering an area of approximately $30 \mathrm{~km}^{2}$ (Brunetti et al. 2013). During the Pliocene the area was affected by tectonic activities which allowed the upward movement of deep hydrothermal fluids, causing the deposition of an endogenic travertine sequence (De Filippis et al. 2013). Because of the large use of travertine for architecture since Roman times, the plain is characterized by an open pit extraction area consisting of a number of abandoned and active quarries located in the center of the basin. The area encompassed by the quarries is approximately $4.7 \mathrm{~km}^{2}$ and is situated between several recent urban settlements. The Regina and Colonnelle springs are the main thermal springs of the aquifer, located approximately $1 \mathrm{~km} \mathrm{NW}$ of the extraction area, along a $\mathrm{N}-\mathrm{S}$ shear fault zone, with an average temperature of $23-24{ }^{\circ} \mathrm{C}$ and a mean discharge of about $2.5 \mathrm{~m}^{3} / \mathrm{s}$ (Lombardi 2005; Brunetti et al. 2013). The dewatering process due to the travertine mining operations at the pit floor, coupled with the extraction activities performed to supply the Rome Thermal SPA, has remarkable effects on the water table level in the travertine aquifer and on the discharge of the above-mentioned natural thermal springs. These activities in the basin also resulted in damage to private buildings in the urbanized area surrounding the travertine quarries, due to land subsidence beginning in July 2003, when the Italian government declared a state of emergency in the Municipalities of Tivoli and Guidonia (Brunetti et al. 2013).

Many conceptual models have been proposed for the study site (Petitta et al. 2011; La Vigna et al. 2011; Carucci et al. 2012; Brunetti et al. 2013; La Vigna et al. 2013), analyzing the area based on hydrogeologic, hydrodynamic and hydrogeochemical 
data. These studies have substantially contributed to addressing several aspects concerning groundwater flow, interaction between different aquifers, mixing of waters of different origin and water-rock interactions. They pointed out the deep and rapid change induced by human activities in recent years in terms of groundwater flow and water chemistry.

The aim of this study is to review the previous conceptual models, gathering all the information necessary to further define a comprehensive and "evolutionary" groundwater conceptual model, which forms the development basis for management tools, addressing of critical issues, best practice identification and evaluation of potential impacts of alternative land use.

\section{Study area setting}

The Acque Albule Basin is located $20 \mathrm{~km}$ ENE of Rome in the foothills of the carbonate Apennines, in the southwestern part of the Tivoli Plain (Fig. 1). One of the main tributaries of the Tiber River, the Aniene River forms its southern boundary. The Acque Albule Basin appears as a morphological depression dipping southward and lying at a mean altitude of about $70 \mathrm{~m}$ a.s.l. In the basin active thermal springs, sinkholes and other karstic features are located (Pentecost and Tortora 1989; Minissale et al. 2002; Salvati and Sasowsky 2002; Billi et al. 2006).

Due to the proximity of Rome, the area has been subjected to increasingly intense anthropization. Nowadays population density exceeds 900 inhabitants per square kilometer. Urban development has not been followed up with the necessary attention, leading to uncontrolled housing and the occurrence of numerous problems. Soil mechanics and foundation engineering are of greatest concern because of the geologic - hydrogeologic setting and occurrence of subsidence (Fig. 1).

Initially only travertine lying above the water table was extracted and the Thermal SPA were supplied by the open-channel intake of the Regina and Colonnelle springs. Downstream of the Thermal SPA, water was carried to the Aniene River by another open-channel, along an ancient Roman ditch. Since the early 1990s the increasing demand for building material led to the deepening of the quarries floors, for an estimated overall amount of extracted travertine about $35^{*} 10^{6} \mathrm{~m}^{3}$. In fact, a large system of sumps and pump stations were set up in order to achieve the required dewatering and two main concrete channels (Pastini and Longarina - in the northern and southern areas, respectively) were built to carry water away to the Aniene River. Unpublished data show that the total discharge of the two channels has increased from $0.64 \mathrm{~m}^{3} / \mathrm{s}$ to $1.57 \mathrm{~m}^{3} / \mathrm{s}$ for the Longarina ditch, and from $1.52 \mathrm{~m}^{3} / \mathrm{s}$ to $1.63 \mathrm{~m}^{3} / \mathrm{s}$ for the Pastini ditch. Investigations confirmed dewatering to be substantial and mainly focused in the northern part of the extraction area. Eight active quarries have been excavated below the water table. In addition, the water demand of the Thermal SPA increased from $0.62 \mathrm{~m}^{3} / \mathrm{s}$ in 1998 to approximately $0.70 \mathrm{~m}^{3} / \mathrm{s}$ in 2000 (operating period: MayOctober). Moreover, during the summer of 2002 (a particularly dry one) additional 


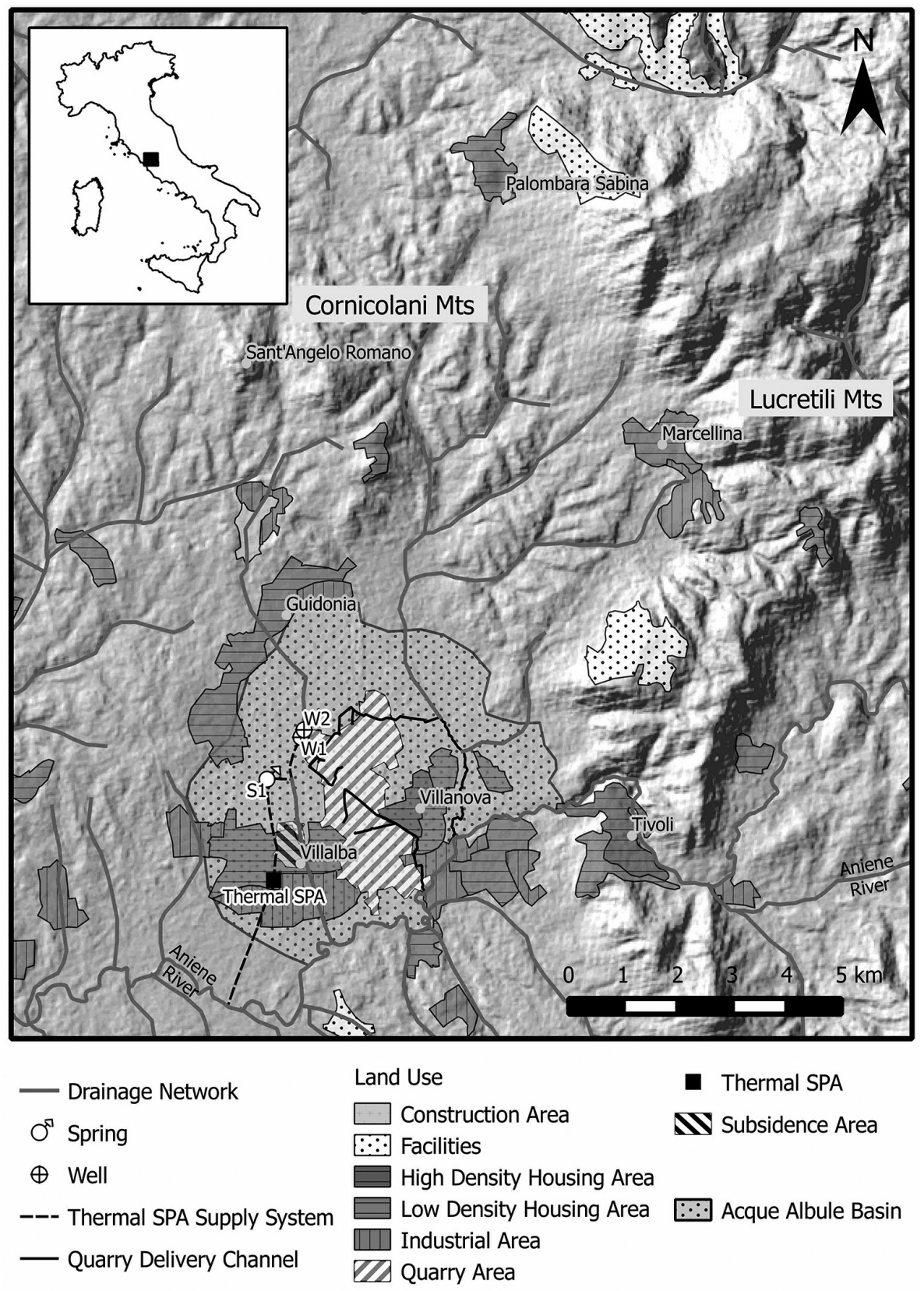

Fig. 1

Plain view of the study area. S1: Regina and Colonnelle springs; W1 and W2: Thermal SPA withdrawal wells 
withdrawals began to integrate the flow rates conveyed to the Thermal SPA by an airlift pumping station located at the Regina spring. As a result, spring discharge
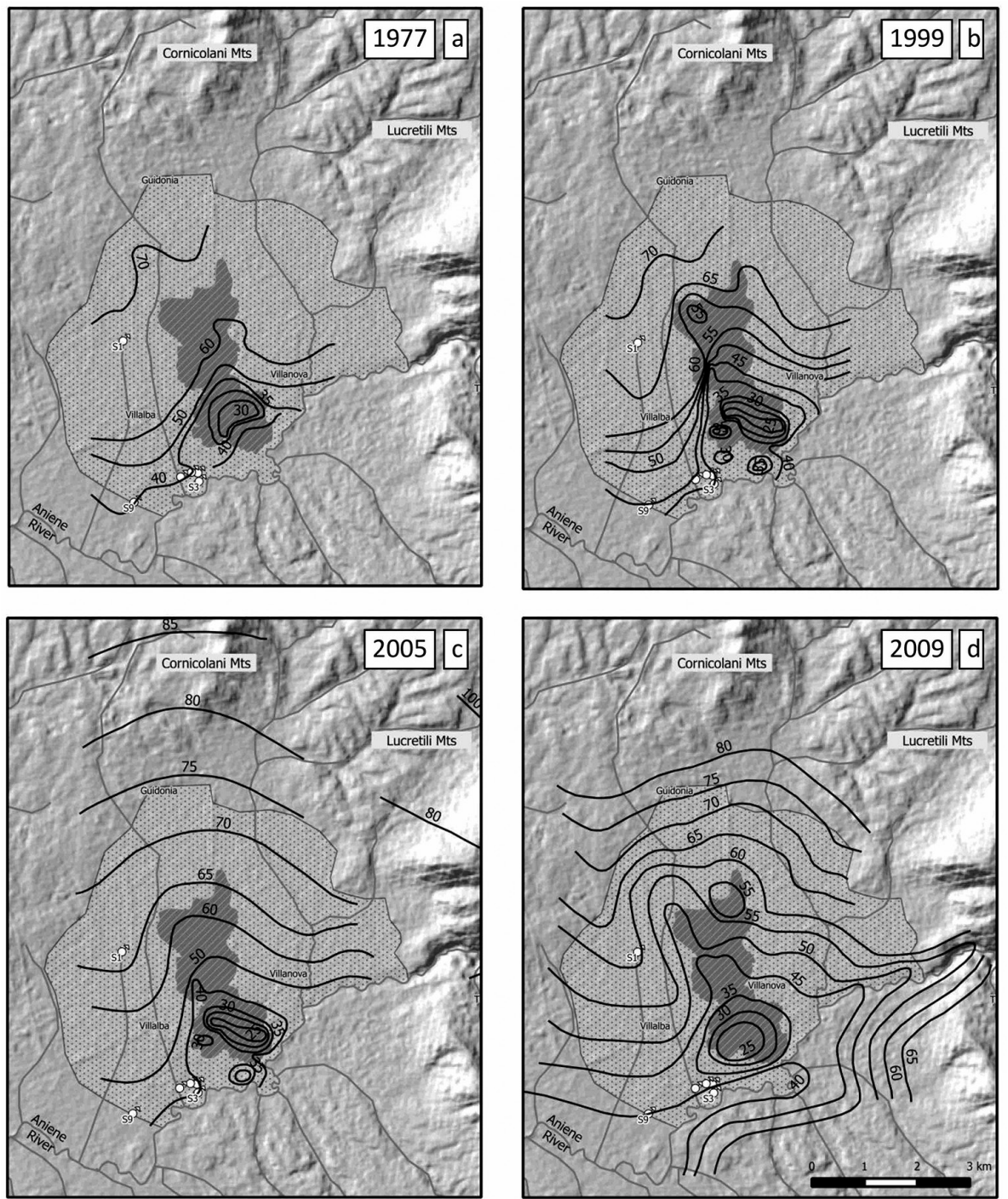

— Piezometric Level (m a.s.I.)

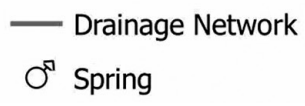

\section{ZZ Quarry Area \\ $\because \because$ Acque Albule Basin}

Fig. 2

Contours of the water table elevation over time. a) 1977 (unpublished data), b) 1999 (unpublished data), c) 2005 (unpublished data), d) 2009 (La Vigna et al. 2013 mod.) 
temporary ceased. Since July 2007 this supply system has been replaced by two wells (W1 and W2) and connected to the Regina and Colonnelle springs (S1) via an underground pipeline (Brunetti et al. 2013).

According to Brunetti et al. (2013) private wells in the area extract less than 0.02 $\mathrm{m}^{3} / \mathrm{s}$. This value can be considered negligible with respect to the volumes circulating in the groundwater system as a whole. The increasing withdrawals from the Acque Albule travertine aquifer have caused a drastic lowering of the water table in the past decades throughout the study area. Figure 2 shows some time steps.

One of the main information gaps is the lack of a real undisturbed reconstruction of the piezometric surface, for which reason the 1977 piezomatric map (Fig. 2) has been taken into account. The natural aquifer flow direction is north-to-south. In the nearby area of the Regina and Colonnelle springs (S1), groundwater flow and water table coincided with the ground elevation (68 $\mathrm{m}$ a.s.1.). Water levels have declined up to $15-20 \mathrm{~m}$ in the southern portion of the quarry area between 1977 and 2005 (Fig. 2). Drops of approximately $5 \mathrm{~m}$ occurred close to the Regina and Colonnelle springs (Brunetti et al. 2013).

The dewatering effect in the quarries area is beyond doubt, but the withdrawals through the Regina spring triggered important consequences downgradient as well. Table 1 shows some historical discharge records of the Regina and Colonnelle springs (S1).

Table 1

Flow rate of Regina and Colonnelle springs (Brunetti et al. 2013)

\begin{tabular}{lllllll}
\hline Year & 1860 & 1896 & 1977 & 1980 & 1987 & 2007 \\
\hline Discharge $\left(\mathrm{m}^{3} / \mathrm{s}\right)$ & 5.860 & 1.517 & 2.500 & 2.000 & 2.050 & 0 \\
\hline
\end{tabular}

The flow rates of the Bretella (S9) and Barco (S3) thermal springs, located along the northern bank of the Aniene River, have also drastically decreased: from 0.45 $\mathrm{m}^{3} / \mathrm{s}$ (June 1998) to $0.09 \mathrm{~m}^{3} / \mathrm{s}$ (February-May 2005) and from $0.35 \mathrm{~m}^{3} / \mathrm{s}$ (June 1998) to $0.12 \mathrm{~m}^{3} / \mathrm{s}$, respectively (La Vigna et al. 2013; Brunetti et al. 2013).

The time trend of the water table and springs flow rates are unquestionable proof of overexploitation occurring at basin scale. This scenario may be exacerbated by natural variations of water availability, as happened in the summer of 2002, when a drought worsened the persistence of the water scarcity conditions. The water table decrease has led to the initiating of consolidation processes which have compromised the stability of several buildings.

The present-day heavy urbanization, the intensive and extensive quarrying activities and the therapeutic-recreational use of thermal waters have spread so far that, at first glance, their mutual interference seems to form an almost inextricable tangle. In this context groundwater plays different roles: an obstacle to remove for mining production, a resource for Thermal SPA, and a matter of concern for building safety. 


\section{Geologic and hydrogeologic setting}

The Cornicolani and Lucretili mountain groups belong to the inner sector of the Central Apennine fold-thrust belt. They consists of Meso-Cenozoic carbonate thrust sheets, migrated eastward during the Neogene as a consequence of Adriatic Plate subduction (Malinverno and Ryan, 1986; Patacca et al. 1992; Doglioni et al. 2007). During the middle-upper Pleistocene, crustal extension caused volcanic activity and a new tectonic regime overlapping the pre-existing geologic pattern. In the Acque Albule area, tectonics led to the formation of a pull-apart subsiding basin characterized by a north-striking, right-lateral, seismically-active fault system and $\mathrm{N} 40^{\circ} \mathrm{E}-\mathrm{N} 60^{\circ} \mathrm{E}$ extensional structures. The fault system is partially overburdened by travertine deposits and crops out in the carbonate Cornicolani Mountains (Maiorani et al. 1992; Faccenna et al. 1994; Sagnotti et al. 1994; Gasparini et al. 2002; Florindo et al. 2004; Billi et al. 2006; Faccenna et al. 2008; Petitta et al. 2011; Carucci et al. 2012).

This tectonic pattern promoted the upward movement of deep hydrothermal fluids and the progressive filling of the subsiding basin by endogenic travertine deposits (Faccenna et al. 2008). This sequence has an average thickness of about $60 \mathrm{~m}$, and its maximum $(85 \mathrm{~m})$ is located near the N-S oriented fault zone (Faccenna et al. 2008). Silty clay with high organic content and peat cover the travertine plateau, reaching a maximum thickness of $5 \mathrm{~m}$. Plio-Pleistocene marine, alluvial, lacustrine, and epivolcanic deposits lie below the travertine, but they crop out in the upper and northern part of the Tivoli Plain and overlie transgressively the thrust sheets of Jurassic-Miocene carbonates (Faccenna et al. 2008). Only scattered data are available concerning the thickness of these deposits; according to some borehole logs and geophysical measurements it may range from a few meters/decameters to some hundred meters (Carucci et al. 2012; La Vigna et al. 2013).

At the base of the succession occurs a Meso-Cenozoic marine carbonate bedrock, at least $4-5 \mathrm{~km}$ thick and formed by limestone, dolostone and marly limestone. The top of this bedrock is encountered at depths ranging between $100-600 \mathrm{~m}$ a.s.1.

The Aniene River and the pyroclastic deposits of the Colli Albani volcanic complex border the southern margin of the Acque Albule Basin. De Rita et al. (1995) dated the volcanic products between 500 and $350 \mathrm{ka}$. Travertine emplacement began during the late Pleistocene just after the end of Colli Albani volcanic activity (Faccenna et al. 2008) and occurred intermittently between about 115 and $30 \mathrm{ka} \mathrm{BP}$ (Petitta et al. 2011).

The carbonate ridges (Lucretili-Tiburtini-Cornicolani Mountains) have been recognized as the recharge areas for the Tivoli Plain, including for the travertine aquifer (Petitta et al. 2011). The infiltration rate is very high because of the widespread karst features: $70 \%-80 \%$ of the annual $1000-1200 \mathrm{~mm}$ rainfall. This process leads to a total discharge of about $7 \mathrm{~m}^{3} / \mathrm{s}$, of which $4 \mathrm{~m}^{3} / \mathrm{s}$ feeds the travertine aquifer (Boni et al. 1986). The natural outlets of this groundwater circulation are the Colonnelle and Regina springs (2 to $3 \mathrm{~m}^{3} / \mathrm{s}$ ), some minor springs and the Aniene River $\left(1 \mathrm{~m}^{3} / \mathrm{s}\right)$. The average flow rate of the Aniene River is about $27 \mathrm{~m}^{3} / \mathrm{s}$ (Boni et al. 1986) inhibiting the identification of possible streambed increases. 
Rainfall recharge in the Acque Albule Basin plays a secondary role feeding the travertine aquifer. The calculated mean effective infiltration rate is about $270 \mathrm{~mm} /$ year, but an high variability has been observed in last decades (Brunetti et al. 2013).

The hydrogeologic setting of the Acque Albule Basin can be summed up as a multilayer aquifer-aquitard system. In detail, the travertine aquifer is fed by seepage occurring from carbonate ridges through the shallow aquifer of Plio-Pleistocene alluvial and volcanic layers (mainly at the foothills of the carbonate Cornicolani Mountains). The travertine consists of calcite and a very minor detrital fraction (Carucci et al. 2012). Spring groundwater is generally saturated or oversaturated with respect to calcite, which explains the travertine deposition (Minissale et al. 2002). According to Faccenna et al. (2008) and De Filippis et al. (2013), three depositional facies of travertine have been recognized in the Tivoli area. The first facies is related to vertical aggradation in shallow "lakes" fed by thermal springs and progradates, from north to south, toward the lowest-lying areas. It is compact and massive, interrupted by five erosion surfaces. The second facies is called "testina", typical of a marsh depositional environment; it overlies the first one separated by the most recent erosion surface. The third facies was deposited in a high-energy environment of the waterfalls along the banks of the Aniene River.

The Acque Albule aquifer is only partially confined at its top by recent clay deposits and semi-confined at its base by Pliocene clay and alluvial and low-permeability volcanic layers. These layers cover the deep confined aquifer contained in the downthrown Meso-Cenozoic carbonates, in which mineralized hot water and gas fluids circulate. This aquifer is fed by the same carbonate ridge (Petitta et al. 2011). In fact, it is difficult to quantify what the contribution of the two flowpaths to spring discharge is. Tectonic discontinuities act as preferential pathways for the upwelling of deep mineralized groundwater, especially along the shear-zone of the Acque Albule, and its mixing with the shallow fresh groundwater. These processes can explain the high mineralization and relatively low temperature of travertine groundwater and its stratification with depth (Faccenna et al. 2008; Petitta et al. 2011; Carucci et al. 2012; La Vigna et al. 2012). Groundwater moves predominantly N-S within the travertine aquifer. The Aniene River represents its base level. In areas not impacted by withdrawals, the hydraulic gradient has been estimated between $0.5 \%$ and $1.0 \%$ (Carucci et al. 2012).

All of this information has been summarized and integrated with the results of the new investigations for the implementation of the conceptual model illustrated in the Results and Discussion Section (see Fig. 4).

The temperature and hydraulic head difference between deep and shallow aquifer are the drivers of the constant upward recharge along fractures and conduits (Faccenna et al. 2008; Petitta et al. 2011). For the high sulfates content and for the warm temperatures of thermal springs of Acque Albule, Primavera (2007) suggests the likelihood of a deep interaction of the incoming recharge water with the evaporites of the Meso-Cenozoic sequence and the existence of the exothermic hydration reaction 
of anhydrite. The same author evaluated the depth of the water source at about 1,600 meters below ground level on the basis of the available bibliographic data (Fournier and Rowe 1966; Hardie 1967; Hanshaw and Bredehoeft 1968; Fontes and Zuppi 1976; D'Amore and Panichi 1980; Jowett et al. 1993; Testa and Lugli 2000; Chiodini et al. 2007). Using borehole data, Primavera (2007) estimated a geothermal gradient of 23 $\mathrm{m} /{ }^{\circ} \mathrm{C}$, an average reservoir temperature of $87^{\circ} \mathrm{C}$, an anhydrite depth of not less than 1200 to 700 meters below ground level. In fact it cannot be excluded that the geothermal anomaly of the area is linked to the proximity of Colli Albani volcanic complex (Petitta et al. 2011; Brunetti et al. 2013).

\section{Materials and Methods}

\section{Hydrogeologic investigations and groundwater modeling}

Pumping tests have been carried out in order to evaluate the hydrodynamic parameters of the aquifer (transmissivity and specific yield) used to implement a numerical flow model (Brunetti et al. 2013).

Flowmeter tests have been performed to assess the existence, directions and magnitude of vertical flows in the piezometers. These measurements were also used to plan multilevel water sampling corresponding to the fracture depths using a removable packer system (Carucci et al. 2012).

Specifically, two deep wells W1 and W2 (Fig. 3) were drilled near the northwestern margin of the quarries area, in order to supply Thermal SPA with water having the greatest possible similar chemical characteristics of the Regina and Colonnelle springs. They were drilled to depths of $70 \mathrm{~m}$ (W1) and $90 \mathrm{~m}$ (W2) and screened to tap the full thickness of the travertine aquifer. Each well has been provided with a total screened piezometer (P1 and P2) located $10 \mathrm{~m}$ north of the well. These wells and piezometers were used to acquire stratigraphic and hydrodynamic data.

The hydrodynamic parameters of the travertine aquifer were obtained by 32-hour pumping tests with a steady pumping rate of about $0.25 \mathrm{~m}^{3} / \mathrm{s}$. The water table drawdown was monitored at piezometers P1 and P2 by pressure transducers during the pumping and recovery phases; data were processed with the Waterloo Aquifer Pro 3.5 software to evaluate transmissivity and specific yield.

During 2009 two flowmeter tests were carried out at P1 and P2, to verify the existence, the direction and the magnitude of vertical fluxes (Paillet 1998) through the fractures and conduits characterizing the travertine aquifer. The tests were performed both in dynamic and natural flow conditions using an HFP-2293 Heat-Pulse flow-meter of Mount Sopris (Petitta et al. 2010; Mastrocicco et al. 2013).

To evaluate and quantify over time each anthropogenic impact on groundwater flow, groundwater monitoring points were installed at the Regina spring (S1), along the southern delivery channel (Longarina) and in the area affected by land subsidence (P16 and P17 piezometers; Fig. 3) (Prestininzi 2008). Meteorological data were 


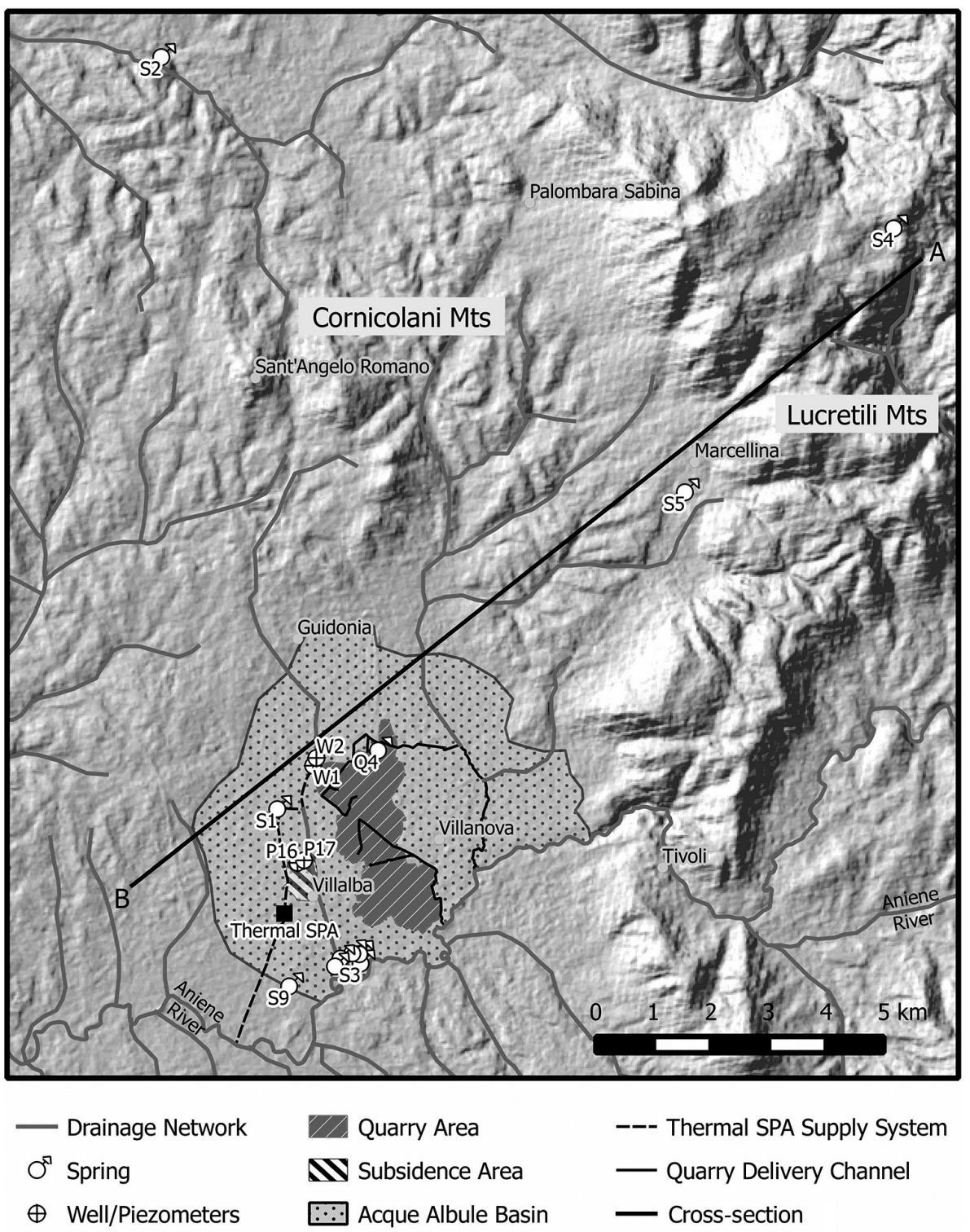

Fig. 3

Location map of the main monitoring points within the Acque Albule Basin. S1: Regina and Colonnelle springs; S2: Cretone spring; S3: Barco spring; S4: Campitello spring; S5: Caprara spring; S9: Bretella spring; Q4: quarry monitoring point; P16 and P17: monitoring piezometers; W1 and W2: pumping wells. A-B: trace of cross-section represented in Fig. 4 
analyzed in order to assess rain water recharge in the Acque Albule Basin, useful to build the groundwater flow model following the procedure suggested by Capelli et al. (2005). Rainfall and temperature data of the Tivoli weather station (Regional Hydrographic Network) were processed to calculate the mean annual precipitation and temperature.

In addition to the above-described hydrogeologic investigations, a numerical flow model has been proposed to calculate the water budget and isolate the effects of individual anthropogenic activities on the Acque Albule Basin groundwater regime (Brunetti et al. 2013). The software FEFLOW 5.4 (DHI-WASY, 2009) was used to implement the flow model. FEFLOW is a finite element groundwater flow model capable of simulating three-dimensional steady-state, transient groundwater flow under saturated or variably saturated conceptualizations and solute mass and heat transport. FEFLOW has been employed to determine quarry dewatering rates and to simulate and analyze the impacts of the open pit dewatering scheme and the Thermal SPA sump station on the groundwater flow system (Brunetti et al. 2013).

\section{Hydrogeochemical investigations and geochemical modeling}

In order to improve knowledge of groundwater flow in the complex environment of the Acque Albule Basin, specific hydrogeochemical investigations and numerical modeling were carried out.

To individuate the sources of recharge of the travertine aquifer and to determine the origin of solutes and the mixing processes in groundwater which occur in the Tivoli Plain, Carucci et al. (2012) adopted an approach based on combined hydrogeochemical and isotopic investigations.

The dataset consists of chemical and isotope analyses of seven springs, one lake, eight groundwater samples rising from fractures inside the quarries, and nine well samples, including multilevel sampling collected with bailer and packer systems, and vertical hydrogeochemical logs. The sampling surveys were performed two times per year between 2008 and 2009 (Carucci et al. 2012).

Hydrogeochemical characterization, coupled with ion-relationship analyses such as $\mathrm{DIC} / \mathrm{Cl}^{-}, \mathrm{Ca} /(\mathrm{Ca}+\mathrm{Mg}) / \mathrm{SO} 4 /\left(\mathrm{SO}_{4}+\mathrm{HCO}_{3}\right)$, was performed to distinguish the different groundwater hydrochemical facies. Environmental isotopes $\left(\delta^{18} \mathrm{O}, \delta^{2} \mathrm{H}\right.$, ${ }^{87} \mathrm{Sr} /{ }^{86} \mathrm{Sr}, \delta^{34} \mathrm{~S}$ and $\delta^{13} \mathrm{C}$ ) were used to identify recharge areas, flowpaths, physical, chemical and mixing processes between shallow and deep groundwater.

Carucci et al. (2012) used a geochemical modeling approach for quantifying the geochemical reactions occurring along the flowpaths within groundwater systems. Geochemical modeling of aqueous systems is based on the assumption of chemical equilibrium among the dissolved species (Plummer 1992) and was used to develop a conceptual hydrogeologic model regarding the mixing processes in the travertine aquifer. Standard geochemical codes, as NETPATH (Plummer et al. 1994) and PHREEQC (Parkhurst and Appelo 1999) have been used to approach the quantitative assessment of mixing and reaction in groundwater. 


\section{Results and Discussions}

In looking at the hydrogeologic characterization of the Acque Albule Basin, the pumping tests showed the relatively high hydraulic conductivity $\left(5.3 \times 10^{-3} \mathrm{~m} / \mathrm{s}\right.$; transmissivity: $0.2 \mathrm{~m}^{2} / \mathrm{s}$ ) of the travertine aquifer unit, with a specific yield of 0.01 (Petitta et al. 2011; Brunetti et al. 2013).

From the vertical flow-velocity trends recorded during flowmeter tests at P1, it was possible to assume the presence of two zones of intense fracturing located between 45 and 63 meters b.g.l., characterized by rapid change in flow direction recorded at a depth of about $55 \mathrm{~m}$ and a velocity peak of $136 \mathrm{~m} / \mathrm{d}$. Concerning piezometer P2, both in dynamic and static conditions, the presence of fractures at around $50 \mathrm{~m}$ of depth (vertical velocity up to $280 \mathrm{~m} / \mathrm{d}$ ), and a wider system of fractures between 55 and 70 $\mathrm{m}$ were detected.

The analysis of the piezometric level data (S1, P16, P17) has shown a continuous lowering of the water table due to the seasonal pumping performed by the Thermal SPA coupled with the on-going quarry dewatering activities. This is proved by the increase of discharge recorded in the Longarina quarry delivery channel (Brunetti et al. 2013). Therefore the travertine aquifer is characterized by high transmissivity and by a groundwater flow occurring mainly through fractures and conduits, especially in the lower portion of the travertine unit (Carucci et al. 2012). These characteristics make the aquifer sensitive not only to anthropic activities (groundwater availability), but also in terms of groundwater quality because of the rapid propagation of the changes through fracture network.

Results of the groundwater flow-modeling indicated that the dewatering activities in the quarries have seriously modified the groundwater flow pattern within the Acque Albule Basin, with a detrimental effect on the basin-scale water budget, including an $85 \%$ reduction in hydrothermal discharge to the surface at the Regina and Colonnelle Lakes. About 25\% loss in Barco and Bretella spring discharge and a water level drop of about $2.9 \mathrm{~m}$ in the area affected by land subsidence have been evaluated (Brunetti et al. 2013). In addition, the model predicted that when quarry dewatering rates were reduced by $30 \%$ the system would recover the natural conditions at the Regina and Colonnelle Lakes, and that the groundwater level would rise by about $3.0 \mathrm{~m}$ in the area affected by land subsidence. The good match between the simulated and observed data suggests that the model is a partial but credible representation of the complex groundwater flow system at the Acque Albule Basin (Brunetti et al. 2013).

The geochemical investigation, focused on the mixing processes, rock-water interactions and determining the recharge areas of the basin, highlighted that the hydrochemistry of groundwater is characterized by relevant mixing processes.

In the conceptual model (Fig. 4), the main recharge area is located in the surrounding carbonate range (Facies A); the groundwater pathways split in two directions, one feeding the travertine aquifer laterally from the north, the second entering the deeply buried carbonate aquifer, where the evaporite rocks enrich groundwater in sulfates and gas $\left(\mathrm{CO}_{2}, \mathrm{H}_{2} \mathrm{~S}\right)$, and heating up (Facies $\left.\mathrm{C}\right)$. Part of this deep circulation rises 


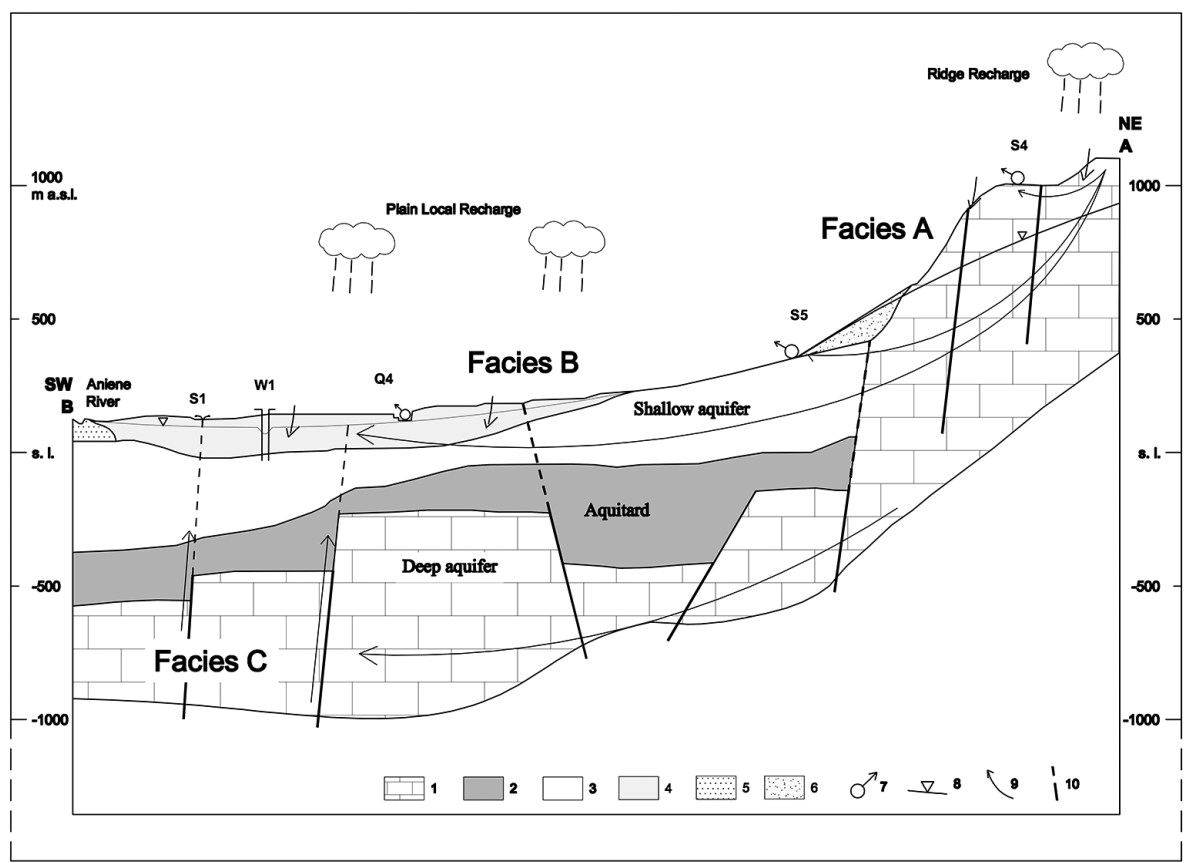

Fig. 4

Conceptual hydrogeological and hydrogeochemical cross-section from hydrological, geochemical and isotope results (A-B trace is shown in Fig. 2). 1: Meso-Cenozoic carbonate aquifer; 2: Plio-Pleistocene aquitard; 3: Pleistocene volcanic and alluvial layers; 4: travertine aquifer; 5: Aniene river deposits; 6: colluvium; 7: spring; 8: water table; 9: ground water flow path; 10: main faults; S1: Regina and Colonnelle springs; W1: pumping well; Q4: quarry monitoring point; S5: Caprara spring; S4: Campitello spring (from Carucci et al. 2012 mod.)

through the fault system and the aquitard, enriching in dissolved ions. Then it mixes with the fresh groundwater of the Acque Albule aquifer, which also receives the contribution of rainfall infiltration through the recent sediments of the plain (Carucci et al. 2012).

The stable isotope data $\left({ }^{18} \mathrm{O},{ }^{2} \mathrm{H},{ }^{13} \mathrm{C}\right.$ and $\left.{ }^{34} \mathrm{~S}\right)$ support this conceptual model and represent key data to quantify the geochemical mixing of the different groundwater circulating in the Tivoli Plain (Carucci et al. 2012). Geochemical and isotope modeling also show an increasing influence of groundwater from the deeply buried aquifer on the travertine aquifer. The extraction activity is modifying the main geochemical characteristics of the travertine aquifer because deep mineralized groundwater is extracted during quarry exploitation, enhancing mixing processes.

The review of past contributions and the recent hydrogeologic and hydrogeochemical studies allowed a deeper insight of the anthropic and natural issues affecting the Acque Albule Basin. This cognitive process resulted in the formulation of a flowchart which allows the development of a conceptual model "wider and wiser" than 
those previously formulated on the basis of specific needs, instances or emergencies, not least because it takes these previous experiences into consideration.

The conceptual model of the Acque Albule Basin will be enhanced taking into account the following components: anthropic activities, hydrologic data and geologic setting. Since the purpose of the model is to address land management concerns and issues, the time factor must be accounted for in a comprehensive conceptual model. This approach must be based on a sound geodatabase in which all the available information is gathered/collected, updated and processed (Fig. 5).

The amount of such information is conveyed in a logical framework represented by the conceptual model. This is basic for numerical modeling implementation (flow, transport, heat, management), for defining lack of information and for identifying how to fill in missing data. An iterative process must be implemented, able to address land management possibilities/potentialities, best practices, critical points and risk-hazard analysis.

Numerical modeling should be enhanced, extending the domain to the carbonate ridge (recharge area) in order to better imitate both groundwater flows (in the shallow travertine aquifer and in the deep carbonate aquifer) and their interaction/mixing. Scattered data are available on hydrodynamic parameters. In the entire study area hydrodynamic characterization tests and hydrogeologic surveys are basic to address this issue. The western and eastern margins of the aquifer are considered to be lat-

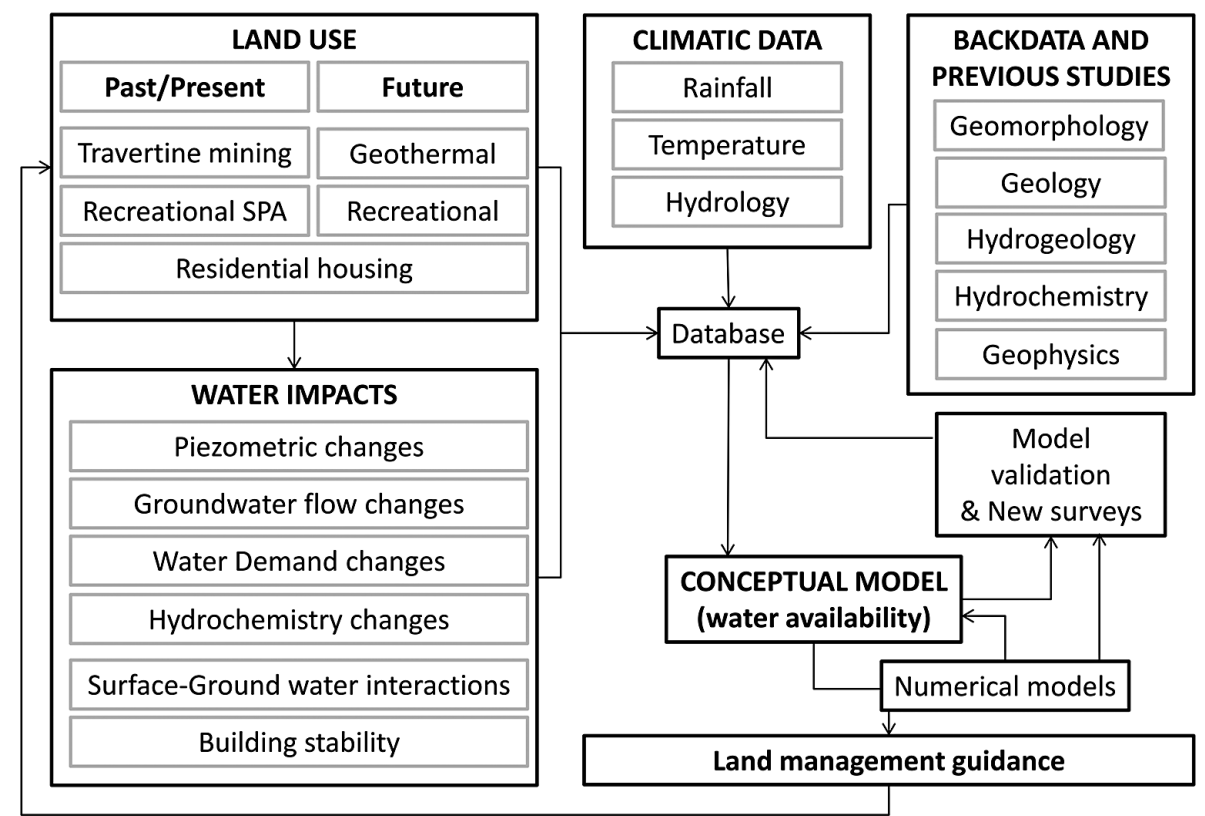

Fig. 5

Conceptual model flow-chart 
eral no-flow boundaries (Brunetti et al. 2013), but dewatering of quarries may have caused an interaction between surface waters of the Aniene River and the travertine aquifer groundwater (Carucci et al. 2012). This issue deserves necessary consideration as well. Future research will also estimate the relative importance of other potentially relevant flow mechanisms such as thermal and density-dependent processes. Additional on-site investigations may help to look into these important issues: high-definition reflection seismic surveying, geoelectrical and gravimetric measurements, deep borehole drilling, implementation of a wider piezometric monitoring network, pumping and slug tests, and heat-flow tests.

Some open questions of not-trivial relevance remain unsolved. In the Acque Albule Basin the origin of the thermal anomaly may be due to post-volcanic heat, exothermic hydration of anhydrite, thermally active volcanic complexes or a combination of these. Furthermore, heat-flow needs to be better surveyed, understood and modeled for two reasons of unquestionable importance: i) to evaluate its likely influence on groundwater circulation (especially the deep one), and ii) to assess the feasibility and the potential of low and medium/high-enthalpy geothermal applications.

\section{Conclusions}

In the Acque Albule Basin, a serious worsening of the anthropic impact on water resources is ongoing for over ten years. The massive withdrawals from the travertine aquifer system have become greater than the groundwater recharge. This progressive dewatering at basin scale has led to an almost constant lowering of the water table, which led to a decrease of spring discharges, to land subsidence, to a remarkable change of the groundwater pathways, to the disappearing of the natural double layer density of the travertine groundwater, probably as seepage of surface water from the Aniene River and to a change of hydrogeochemistry. The deepening of pit floors has opened new preferential pathways and has caused the outcropping of large fractures and faults. Important changes will affect the basin as a consequence of the future redevelopment of the quarries areas. Both hydrogeology and hydrochemistry of the Acque Albule aquifer will be involved and this will certainly create other environmental and anthropic impacts. The natural variability in water resources worsens this compromised scenario even more. The peculiar physico-chemical characteristics of Acque Albule groundwater make them a valuable resource that must be safeguarded for thermal and recreational purposes. Important and rapid changes are being considered and will affect land use and hence water resources.

Beginning with a critical review of the previous studies, a methodology to implement a more detailed conceptual model of the Acque Albule has been presented in this paper. It accounts both for natural phenomena affecting the aquifer and for the anthropic impact, which must be forecasted, in particular the restoration of the quarry areas. This model can be a sound basis to address future surveys, research and numerical model implementations. Eventually it can become a useful tool to support 
land management decisions when it is tightly coupled with a functionally-robust geodatabase and related numerical models.

The database plays a basic role in the collection, updating and processing of the available multidisciplinary data. It organizes the information in a logical framework, useful for the development of the conceptual model. The conceptual model itself drives the implementation of different types of numerical models: groundwater flow and transport, geochemical reactions, heat flow, and water resource management. Their output is conveyed back to the conceptual model for further updating, but above all to be used as an objective structure for land management and decision-making. The described framework may be considered as part of a more complex tool for hazard-risk analysis and management.

\section{Acknowledgements}

Thanks go to the CE.RI. Research Center for Forecast, Prevention and Control of the Geologic Risks of the University of Rome, Sapienza (Italy) for the assistance and technical support. In particular, the authors are very grateful to Prof. Alberto Prestininzi, Dr. Gianluca Bianchi Fasani and Dr. Carlo Esposito for their suggestions.

\section{References}

Abe H., C. Tang, A. Kondoh 2014: Effect of urban aquifer exploitation on subsurface temperature and water quality. - Groundwater, 52, pp. 186-194.

Billi, A., A. Valle, M. Brilli, C. Faccenna, R. Funiciello 2006: Fracture-controlled fluid circulation and dissolutional weathering in sinkhole-prone carbonate rocks from central Italy. - Journal of Structural Geology, 29, pp. 385-395.

Boni, C., P. Bono, G. Capelli 1986: Schema idrogeologico dell'Italia Centrale. - Memorie Società Geologica Italiana, 35, pp. 991-1012.

Brunetti, E., J.P. Jones, M. Petitta, D.L. Rudolph 2013: Assessing the impact of large-scale dewatering on fault-controlled aquifer systems: a case study in the Acque Albule basin (Tivoli, central Italy). Hydrogeology Journal, 21, pp. 401-423.

Capelli, G., R. Mazza, C. Gazzetti 2005: Strumenti e strategie per la tutela e l'uso compatibile della risorsa idrica nel Lazio. Gli acquiferi vulcanici. - Pitagora, Bologna, 191 p.

Carucci, V., M. Petitta, R. Aravena 2012: Interaction between shallow and deep aquifers in the Tivoli Plain (Central Italy) enhanced by groundwater extraction: a multi-isotope approach and geochemical modeling. - Applied Geochemistry, 27, pp. 266-280.

Chiodini, G., A. Baldini, F. Barbieri, M.L. Carapezza, C. Cardellini, F. Frondini, D. Granieri, M. Ranaldi 2007: Carbon dioxide degassing at Latera caldera (Italy): evidence of geothermal reservoir and evaluation of its potential energy. - Journal of Geophysical Research, 112, pp. 1-17.

D'Amore, F., C. Panichi 1980: Evaluation of deep temperatures of hydrothermal systems by a new gas geothermometer. - Geochimica et Cosmochimica Acta, 44, pp. 549-556.

De Filippis, L., C. Faccenna, A. Billi, E. Anzalone, M. Brilli, M. Soligo, P. Tuccimei 2013: Plateau versus fissure ridge travertines from Quaternary geothermal springs of Italy and Turkey: Interactions and feedbacks between fluid discharge, paleoclimate, and tectonics. - Earth-Science Reviews, 123, pp. $35-52$. 
De Rita, D., C. Faccenna, R. Funiciello, C. Rosa 1995: Structural and geological evolution of the Colli Albani volcanic district. - In: Trigila, R. (Ed.): The Volcano of the Alban Hills. Tipografia SGS, Rome, pp. 33-71.

Doglioni, C., E. Carminati, M. Cuffaro, D. Scrocca 2007: Subduction kinematics and dynamic constraints. - Earth-Science Reviews, 83, pp. 125-175.

DHI-WASY 2009: FEFLOW 5.4. Finite element subsurface flow and transport simulation system. User's manual - DHIWASY, Berlin.

Faccenna, C., R. Funiciello, M. Mattei 1994: Late Pleistocene N-S shear zones along the Latium Tyrrhenian margin: structural characters and volcanological implications. - Bollettino di Geofisica Teorica e Applicata 36, pp. 141-144.

Faccenna, C., M. Soligo, A. Billi, L. De Filippis, R. Funiciello, C. Rossetti, P. Tuccimei 2008: Late Pleistocene cycles of travertine deposition and erosion, Tivoli, Central Italy: possible influence of climate changes and fault-related deformation. - Global Planetary Change, 63, pp. 299-308.

Florindo, F, F. Marra, P. Montone, M. Pirro, E. Boschi 2004: Palaeomagnetic results from an archaeological site near Rome (Italy): new insights for tectonic rotation during the last 0.5 Myr. Annals of Geophysics, 47/5, pp. 1665-1673.

Fontes, J.Ch., G.M. Zuppi 1976: Isotope and water chemistry in sulfide-bearing springs of central Italy. - In: Interpretation of Environmental Isotope and Hydrochemical Data in Groundwater Hydrology. IAEA editor, Vienna, pp. 143-158.

Foster, S.S.D., K. Vairavamoorthy 2013: Urban Groundwater - Policies and Institutions for Integrated Management. - www.gwptoolbox.org

Foster, S.S.D., A.R. Lawrence, B.L. Morris 1998: Groundwater in urban development: assessing management needs and formulating policy strategies. - World Bank Technical Paper, 390, 55 p.

Foster, S.S.D., R. Hirata, K.W.F. Howard 2011: Groundwater use in developing cities: policy issues arising from current trends. - Hydrogeology Journal, 19, pp. 271-274.

Fournier, R.O., J.J. Rowe 1966: Estimation of underground temperatures from silica content of waters from hot springs and wet steam wells. - American Journal of Science, 264, pp. 685-697.

Galloway, D.L., T.J. Burbey 2011: Review: Regional land subsidence accompanying groundwater extraction. - Hydrogeology Journal, 19, pp. 1459-1486.

Gasparini, C., R. Di Maro, N. Pagliuca, M. Pirro, A. Marchetti 2002: Recent seismicity of the "Acque Albule" travertine basin. - Annals of Geophysics, 45, pp. 537-550.

Hardie, L.A. 1967: The gypsum-anhydrite equilibrium at one atmosphere pressure. - The American Mineralogist Journal, 52, pp. 171-200.

Hanshaw, B.B., J.D. Bredehoeft 1968: On the maintenance of anomalous fluid pressures: II. Source layer at depth. - Geological Society of America Bullettin, 79/9, pp. 1107-1122.

Howard, K.W.F. 2007: Urban groundwater: meeting the challenge. - IAH Selected Paper Series 8, Taylor \& Francis, Oxford, $307 \mathrm{p}$.

Jenerette, G.D., L. Larsen 2006: A global perspective on changing sustainable urban water supplies. Global Planetary Change, 50/3-4, pp. 202-211.

Jowett, C.E., L.M. Cathles, B.W. Davis 1993: Predicting depths of gypsum dehydration in evaporitic sedimentary basins. - AAPG Bullettin, 77, pp. 402-413.

Julio-Miranda, P., A.J. Ortiz-Rodriguez, A.G. Palacio-Aponte, R. Lopez-Doncel, R. Barboza-Gudino 2012: Damage assessment associated with land subsidence in the San Luis Potosi-Soledad de Graciano Sanchez metropolitan area, Mexico, elements for risk management. - Natural Hazards, 64, pp. 751-765.

La Vigna, F., R. Rossetto, R. Mazza, G. Capelli 2011: Can we calibrate a complex groundwater model just by running an automatic calibration code? A case study from Italy: The Acque Albule Plain model (Rome). - IAHS-AISH Publication, 341, pp. 51-56.

La Vigna, F., V. Carucci, I. Mariani, L. Minelli, F. Pascale, M. Mattei, R. Mazza, M. Tallini 2012: Intermediate field hydrogeological response induced by L'Aquila earthquake: the Acque Albule hydrothermal system (Central Italy). - Italian Journal of Geosciences, 131, pp. 475-485. 
La Vigna, F., R. Mazza, G. Capelli 2013: Detecting the flow relationships between deep and shallow aquifers in an exploited groundwater system, using long-term monitoring data and quantitative hydrogeology: the Acque Albule basin case (Rome, Italy). - Hydrological Processes, 27/2, pp. 3159-3173.

Lombardi, L. 2005: Indagini geochimiche per determinare le cause dei dissesti agli edifici di Via Cesare Augusto ed aree limitrofe in località Bagni di Tivoli. - Contratto di Ricerca con la Regione Lazio, 5350 del 11/01/2005.

Maiorani, A., R. Funiciello, M. Mattei, B. Turi 1992: Stable isotope geochemistry and structural elements of the Sabina region (Central Apennines, Italy). - Terra Nova, 4, pp. 484-488.

Malinverno, A., W.B.F. Ryan 1986: Extension in the Tyrrhenian Sea and shortening in the Apennines as result of arc migration driven by sinking of the lithosphere. - Tectonics, 5, pp. 227-254.

Mastrocicco, M., C. Sbarbati, N. Colombani, M. Petitta 2013: Efficiency verification of a horizontal flow barrier via flowmeter tests and multilevel sampling. - Hydrological Processes, 27/17, pp. 2414-2421.

Minissale, A., D.M. Kerrick, G. Magro, M.T. Murrell, M. Paladini, S. Rihs, N.C. Sturchio, F. Tassi, O. Vaselli 2002: Geochemistry of Quaternary travertines in the region north of Rome (Italy): structural, hydrological and paleoclimatic implications. - Earth Planetary Science Letters, 203, pp. 709-728.

Paillet, F.L. 1998: Flow modeling and permeability estimation using borehole flow logs in heterogeneous fractured formations. - Water Resources Research, 34/5, pp. 997-1010.

Parkhurst, D.L., C.A.J. Appelo 1999: Users Guide to PHREEQC (Version 2) - A Computer program for Speciation, Batch Reaction, One-dimensional Transport and Inverse Geochemical Calculations. U.S. Geological Survey, Denver, 326 p.

Patacca, E., R. Sartori, P. Scandone 1992: Tyrrhenian basin and Apenninic arcs: kinematic relations since late Tortonian times. - Memorie della Società Geologica Italiana, 45, pp. 425-451.

Pentecost, A., P. Tortora 1989: Bagni di Tivoli, Lazio: a modern travertine depositing site and its associated microorganism. - Bollettino della Società Geologica Italiana, 108, pp. 315-324.

Petitta, M., V. Marinelli, E. Pacioni 2010: Il contributo delle indagini con heatpulse flowmeter alla valutazione delle componenti verticali del flusso in acquiferi fratturati e porosi. - Engineering Hydro Environmental Geology, 13, pp. 41-50.

Petitta, M., P. Primavera, P. Tuccimei, R. Aravena 2011: Interaction between deep and shallow groundwater systems in areas affected by Quaternary tectonics (Central Italy): a geochemical and isotope approach. - Environmental Earth Sciences, 63, pp. 11-30.

Plummer, L.N. 1992: Geochemical modeling of water-rock interaction: past, present, future. - In: Kharaka, Y.K., A.S. Maest (Eds): Water-Rock Interaction. Proceeding of 7th International Conference Balkema, Rotterdam, pp. 23-33.

Plummer, L.N., E.C. Prestemon, D.L. Parkhurst 1994: NETPATH: An Interactive Code (NETPATH) for Modeling NET geochemical Reactions Along a Flow PATH, Version 2.0. - U.S. Geological Survey, Reston, $231 \mathrm{p}$.

Prestininzi, A. 2008: Relazione conclusiva relativa alle convenzioni stipulate tra il Centro di Ricerca CE.RI. e la Regione Lazio (30/01/2006 e successiva del 04/07/2006), inerente agli studi e alle indagini condotte nelle zone soggette a fenomeni di subsidenza di Tivoli-Guidonia. - CE.RI. La Sapienza, Regione Lazio Protezione Civile, Rome.

Primavera, P. 2007: Caratterizzazione idrogeochimica e confronto dell'area di Tivoli (Roma) con l'area delle terme di Cotilia e Antrodoco (Rieti): considerazioni idrogeologiche. - PhD Thesis, University of Roma III.

Sagnotti, L., C. Faccenna, R. Funiciello, M. Mattei 1994: Magnetic fabrics and structural setting of PlioPleistocene clayey units in an extensional regime: the Tyrrhenian margin of Central Italy. - Journal of Structural Geology, 16, pp. 1243-1257.

Salvati, R., I.D. Sasowsky 2002: Development of collapse sinkhole in areas of groundwater discharge. Journal of Hydrology, 264, pp. 1-11.

Sayyaf M., M. Mahdavi, O.R. Barani, S. Feiznia, B. Motamedvaziri 2013: Simulation of land subsidence using finite element method: Rafsanjan plain case study. - Natural Hazard, 72, pp. 309-322. 
Schreiber, M.E., J.A Simo, P.G. Freiberg 2000: Stratigraphic and geochemical controls on naturally occurring arsenic in groundwater, eastern Wisconsin, USA. - Hydrogeology Journal, 8/2, pp. $161-176$

Taniguchi M., A. Dausman, K. Howard, M. Polemio, T. Lakshmana (Eds) 2009: Trends and Sustainability of Groundwater in Highly Stressed Aquifers. - IAHS Press, Wallingford, $318 \mathrm{p}$.

Testa G., S. Lugli 2000: Gypsum-anhydrite transformations in Messinian evaporites of central Tuscany (Italy). - Sedimentary Geology, 130, pp. 249-268.

Tomas R., G. Herrera, J. Delgado, J.M. Lopez-Sanchez, J.J. Mallorqui, J. Mulas 2010: A ground subsidence study based on DInSAR data: calibration of soil parameters and subsidence prediction in Murcia City (Spain). - Engineering Geology, 111, pp. 19-30

Villholth, K. 2006: Groundwater assessment and management: Implications and opportunities of globalization. - Hydrogeology Journal, 14/3, pp. 330-339.

Whittington, P., J.S. Price 2013: Effect of mine dewatering on the peatlands of the James Bay Lowland: the role of marine sediments on mitigating peatland drainage. - Hydrological Processes, 27, pp. $1845-1853$. 